\title{
Gender differences in school performance and attitudes toward school
}

Carmen Rodríguez Martínez a

Monsalud Gallardo Gil ${ }^{b}$

\section{Abstract}

In this article we address gender differences in school performance and attitudes towards school using data from national (in Spain) and international evaluation reports and qualitative research to understand the perceptions of post-compulsory secondary students who continue their studies and do so successfully. Using a sample of twenty-six students (12 girls and 14 boys) who study Baccalaureate and Vocational Training, we investigate through in-depth interviews the shaping of feminine and masculine identities defined both in the reproduction of stereotyped cultural patterns as well as in the resistance and rupture. The findings reveal that girls have a clearer commitment to school work, being still very underrepresented in technical studies whose importance in the labour market is greater.

Keywords: Gender. School performance. Attitudes towards school. International evaluations.

a University of Málaga, Málaga, Spain

b University of Málaga, Málaga, Spain

Recebido em: 18 mar. 2019

Aceito em: 09 ago. 2019 


\section{Introduction}

In the information society, the situation that knowledge has acquired as a necessary good for economic development focuses interest on the control of Education under comparative standards between countries that seek excellence. Within this framework, the comparative school performances reveal differences by sex in favour of female students that are resulting in a new topic of concern. Reports from the Programme for International Student Assessment, PISA(OECD, 2015a; 2015b; 2015c), of the European Commission (EC, 2017) and the State System of Indicators of Spain (INEE, 2017) have highlighted these differences that are linked to the concern raised by the high rate of school dropout and grade repetitions that also reveal significant differences by gender.

Taking into account these premises, we conducted a qualitative research with Spanish boys and girls from the High School and Vocational Training who continue their studies and do so successfully, even though they may have experienced difficulties, seeking reasons to explain the greater school failure of boys. In Spain, Education is compulsory between 6 and 16 years old and practically all children start at the age of 3 ( $96 \%$ of students). Secondary Education, which is the object of this research, is divided into Compulsory Secondary Education ("ESO", 12-16), Baccalaureate and intermediate-level Vocational Training (16-18). Despite the 25 point increase in the graduation rate in Higher Education, 34\% of students do not reach the upper secondary level, when the Organization for Economic Cooperation and Development (OECD) average is $15 \%$. As in most reports from the OECD, the persistence of a gender bias in the study areas is observed (OECD, 2018).

The results show us that there are social, structural and behavioural factors that reveal a disparity in the attitude and expectations towards studies among students that cannot only be explained by the family and social context that "would push" them to leave their studies, but by factors that "attract" female students -to a greater extent- to the life project offered by the school.

\section{Research on the factors that influence school performance and attitudes towards studies}

Jackson et al. (2007), from an investigation carried out in England and Wales on the transition experienced by 16-year-old students, state that it is a serious error to focus attention exclusively on class differences (socio-cultural at source) to relate them to academic performance, as is often the case in sociological literature, since there are differences due to the decisions taken by the students themselves and the influence of families, teachers and colleagues. 
This leads us to consider not only social and contextual factors linked to the cultural, professional, economic environment and the stimuli of families, which would "push" towards a certain educational level, but to highlight the importance of personal, relational, and educational factors that contribute to elaborating a life project and that "attract" young people towards continued studies; these would mean the benefits and costs of studying, both for young people and their families, as Martínez García has studied for Spain (2011) and Mediavilla and Gallego have done for Brazil (2016). These so-called secondary factors can represent a variability of 25 to $50 \%$ (Jackson et al., 2007).

The students come from the same families, and have similar material and cultural resources, so the rise in the educational level that has occurred in a higher percentage of girls in recent years (see section 3 ) can be explained more by factors that attract them to success than by those that determine their failure.

The differences in performance are also revealing the ability to overcome the effect of social contexts of origin, through other factors as yet little studied. The differences between male and female students are especially evident among those who have low school performance. An example of this is research on gypsy female students (ABAJO; CARRASCO, 2004; CREA, 2010).

Several studies show that feeling satisfaction with the school experience and enjoying it is related to continuing in subsequent educational processes. Female students studied in England and Spain say they enjoy learning more than male students. It is usually a personal experience that has to do with establishing better relationships with teachers and other adults, having male and female friends, varied and attractive pedagogies and support in personal learning (MARCENARO, 2010; GORARD; SEE, 2011).

Another reason that may influence their interest and continuity in studies is that mothers, in this case with little academic Education, consider it essential that their daughters study and have high aspirations about them in the academic field. This would tally with the research of Marcerano (2010), which shows the high intergenerational mobility in girls and their mothers, who have high expectations of school continuity (PADILLA; SUÁREZ; GARCÍA, 2007).

For years, there has been an important line of inquiry that seeks to explore relations with the school considering the differences in the construction of the subjectivity of girls and boys, linked to the social models of femininity and masculinity. There is a growing consensus in recognising that what we consider feminine 
and masculine are social and historical constructions, that go beyond the purely biological border between the sexes. The sex-gender theory means that men and women are differentiated in the sexual division of labour, in the distribution of roles, power, economic stratification and in almost all the categories in which traditional thought has played a part, which are constantly under revision as they are unfinished processes, subject to multiple influences and with sometimes paradoxical movements of choices and restrictions (AMOROS; DE MIGUEL; 2005; POSADA, 2019). In some of these analyses, the strength of subjectivity and the role played by the construction of masculinities and femininities are evident, especially when we talk about adolescents (CONNELL, 2003; RENOLD; ALLAN, 2006;SKELTON; FRANCIS; READ, 2009). In this area, there is an important body of research that has investigated the relationship between the construction of masculinity and the experience of school work (RODRÍGUEZ MENÉNDEZ, 2007; SIERRA, 2013; SUKHNANDAN; KELLEHER, 2000), seeking the acceptance of their classmates. And, although less attention has been paid, we also have some studies on the female students and their relationship with the school (FRANCIS; SKELTON, 2005; FSG, 2006; RENOLD; ALLAN, 2006; SKELTON; FRANCIS; READ, 2009).

To gain peer acceptance, in the early years of high school (14-16 years old) some male students avoid the appearance of being applied to school work, often creating climates of confrontation to school rules and discipline to achieve a leadership that is contrary to good school performance. For Jackson (1998) some boys participate actively in their low performance as a sign of rejection of the school culture. Boys also suffer pressures to adjust to a poor and active masculinity concept (HOLDEN, 2002).

Several male and female authors agree on the importance of feeling part of a group in which they are accepted and that supports them in obtaining their achievements. Francis, Read and Skelton (2009), referring to adolescent students (12-13 years of age), point out that it is not about being popular, but about feeling the support of the peer group. And Akey (2006) argues that a good climate of class helps raise the levels of commitment and competence of the students.

Various explanations have been given to understand the differences in school results between male and female students. Some tend to refer to classical theories about girls' greater adaptation to school culture, to the fact that they are more complacent and submissive to the order and discipline imposed in schools (FERNÁNDEZ ENGUITA, 2009; MARTÍNEZ GARCÍA, 2011; PERRENOUD, 1990). Others point to the different attitudes towards school, school work and 
learning (MARCERANO, 2010; WARRINGTON; YOUNGER; WILLIAMS, 2000) and make clear in their analyses resistance to classic stereotypical models of femininity, especially among female adolescents (KEDDIE, 2005).

\section{Gender differences in school performance and the choice of studies in international reports}

In Europe, a major social and pedagogical challenge is to favour school success and continuity and a political demand to achieve higher rates of student inclusion in post-compulsory secondary Education. From the Council of Europe in 2000, held in Lisbon, Europe proposes a more intense collaboration in educational matters. The European targets (ET 2010 and ET 2020) ${ }^{1}$, assumed by Spain, seek to increase the enrolment rate of young people between 18 and 24 years of age until this reaches $90 \%$ of the population in Europe and $85 \%$ of the population in our country. The data of the European Commission (EC, 2017) confirm that in Spain the dropout rates ${ }^{2}$ are particularly high, $19.8 \%$ above the European Union average of the twenty-eight member states, which stands at 11\%, with Spain being ranked second with more school dropout after Malta. From these data we wish to highlight that boys drop out of school more often than girls $(22.7 \%$ versus $15.1 \%$ ), almost eight points adrift, although not having a high school diploma is a major obstacle to finding employment, especially for women.

Differences in grade repetitions are also appreciable, although the number of boys and girls who attend and complete secondary Education is similar in many countries. Boys account for $60 \%$ of the students who repeat a grade ${ }^{3}$ in the Organization for Economic Cooperation and Development (OECD) (2009), with 10 points of difference with regard to female students, and a larger number of boys leave school without any qualification.

In Spain, although there is a decrease in this percentage, we still have a high rate of repeaters, one out of every three students has repeated before completing compulsory secondary Education (15-16 years), and is twenty points higher than the OECD average (31\% versus $11 \%$ of the OECD) and 16 points higher than the group of European Union (EU) students (INEE, 2017).

\footnotetext{
The documents of the 2020 Strategic Framework for Education and Training can be found at the following link: http://ec.europa.eu/education/policy/strategic-framework_es

2 The European Community speaks of dropout to refer to the population of 18 to 24 year-olds that has completed the first stage of secondary Education, and does not have a qualification or continue studies. In the OECD the dropout rate is considered between 20 and 24 years of age.

3 Although the benefits of repeating a grade are debatable, only about one third of European countries have automatic progression in primary Education (EURYDICE, 2011).
} 
These high rates of repeaters are much higher in male students, revealing a difference with female students of 14 points in PISA 2009 and 11 points in PISA 2012. This shows that the differences in the suitability rate between girls and boys, in the 2014-2015 academic year, is nine points at 15 years of age ${ }^{4}(67.6 \%$ versus $76 \%$ ) and that it will be ascending in the higher grades (INEE, 2017).

In terms of performance differences in boys and girls in the field of studies, the OECD report (2015a) shows stable patterns with the series of data that have been produced in the PISA report since 2000 . At the age of $15,60 \%$ of lowachieving students in maths, reading and science are boys and $40 \%$ are girls. Girls get higher grades and have a higher of passing exams, which should give them a clear advantage in choosing Higher Education, which will not be the case as we will see later.

The gender gap remains in the educational performance in different subjects and increases as students grow. At the secondary level, girls will have a clear advantage in reading, 38 points above in PISA 2012 (40 points in Spain), which is equivalent to one year's schooling. The gap in mathematics represents a much smaller advantage for boys, 9 points on average (15 points for Spain), and is insignificant for some countries (OECD, 2015b).

In university degrees, female students obtained $58 \%$ of the university degrees awarded throughout the OECD; however, there is a gender gap in the fields of study (OECD, 2015b). Females are underrepresented in the fields of Science, Technology, Engineering and Mathematics (STEM), only 20\% of graduates in 2012 were women, while males are underrepresented in Education and Health Sciences where more than $70 \%$ are women. In addition, female students that graduate in STEM exercise professions related to their studies to a lesser extent, and only $43 \%$ do so compared to male students, who reach $71 \%$. The problem of female underrepresentation in STEM careers is not simple, and it is clear that there are gender-related filters that prevent women from pursuing careers, as indicated by Blickenstaff (2006).

Women in Spain are the majority at University by a percentage that is lower than the OECD average (54.4\% compared to $45.6 \%$ for men). The differences in Science are mainly in Engineering, where male students triple female students and depending on the field of Science, whiles females surpass males in Health Sciences by more than double.

Percentage of students who are enrolled in the course corresponding to their age at the end of compulsory secondary Education. 


\section{Gender differences in attitudes towards school in international reports}

According to the OECD report (2015a), the differences in performance persist in all the countries of Europe in favour of girls, the reasons being their positive attitude towards school as opposed to that of boys. An example of this is that girls spend more time on homework: about seven hours a week, compared to the four of boys. Among them, however, the idea that school is a waste of time is much more widespread.

Differences in performance do not correspond to inherent skills among boys and girls in reading and mathematics, but rather that society and schools encourage different attitudes and different levels of confidence towards them (OECD, 2015c). In reading, girls show far more interest and read more complex fiction and nonfiction books, around $75 \%$ of girls say they read for fun, compared to $50 \%$ of boys. However, the gap in mathematics is opposite and one of the reasons is the lack of confidence; two out of three girls versus one out of every two boys report that they fear maths classes because they find it difficult (OECD, 2015a). 15-year-old girls perform on average barely a little worse than boys in maths, but they have much lower levels of interest and enjoyment and much higher anxiety and stress. Throughout the OECD, $62 \%$ of girls believe "they are not good at maths" compared to $52 \%$ of boys (OECD, 2015b).

Although differences in achievement in mathematics and science, according to what international reports reveal, is fairly similar and consistent throughout Europe; there are major differences in the choice of career for a traditional conception of gender roles and acceptance of the cultural values associated with the different fields of study.

And we can add that it does not correspond that the countries with greater development have greater gender equity in access to scientific degrees; on the contrary, to less economic inequalities, gender stereotypes more clearly condition access to them (OECD, 2015b).

In the average of the OECD countries, four times more boys than girls plan to pursue a career in computer science or engineering, reinforced by the expectations of parents who also expect their children to opt for STEM fields. Social, family and work archetypes create a sexual division of labour so that girls focus more on the care and caring professions. Perceptions of what is considered a masculine and feminine "vocation" are formed at an early age and are influenced by gender roles (OECD, 2015b). 
The conclusions are that there are few differences in the students who perform well, although the average of the girls is outperforming the boys. Yet this superiority in academic performance masks the scant participation in technical studies whose importance in the labour market is greater.

The changes have allowed women to have access to Education and spaces that were traditionally exclusively male. But the gender codes that govern these areas continue to maintain a hierarchy between the masculine and the feminine.

\section{Methodology 5}

The data offered in this article are part of a larger study that seeks to investigate the pedagogical factors that favour success and continuity in school for students in post-compulsory secondary Education. Through the narratives and perceptions of students of Baccalauretate (B) and Vocational Modules (VM), we try to understand the effects of gender differences that explain school performance and attitude towards studies.

Semi-structured interviews ( 2 per student on average), with an ethnographic and phenomenological focus (ANGROSINO, 2012), have been carried out, recorded with the consent of the participants and subsequently transcribed for analysis, attempting to understand the school experience from the perspective of the subject, emphasizing the knowledge produced through these and taking care of ethical problems when using conversations for research purposes (KVALE, 2011).

With these interviews, we have explored aspects such as: attitudes towards school and school knowledge; the relationship with Teaching staff, the contents and the activities; and the life meaning of their school experience. As a complement, we have used two additional methodological resources: a context questionnaire, which has provided us with general information to know the family environment in which they live; and the technique of photo-language, to explore, through visual and evocative resources, aspects related to emotions and experiences about their school trajectory and the perception of themselves in this journey through schooling (BAPTISTE; BELISLE, 1991).

The data obtained were organized by the thematic grouping by categories, for which operations of categorization and codification of the data were carried out, which resulted in small research reports. Textual matrices were developed and

The data from this research are part of a larger study funded by the CEA Foundation (PRY031/2011) and carried out by the Andalusian universities. 
allowed comparison between cases and triangulation between sources, techniques and contexts of analysis, taking into account the differences between girls and boys and between Vocational Courses and High School students.

We have selected an intentional sample of 26 students, 16 studying Baccalaureate and 10 studying Vocational Modules, in 12 urban and semi-urban centres in five provinces of southern Spain (Malaga, Seville, Granada, Cádiz and Almería). These are 12 girls and 14 boys, students of Baccalaureate of Social Sciences (9) and Sciences (7), as well as of different branches of Vocational Modules: Computing (4), Health Area (3), Commerce (1) and Tourism (1).

The Teaching staff of the centres have collaborated in the selection of students by responding to one or more of these criteria: a) interest in their studies; b) good grades and c) having overcome previous difficulties - whether personal or social.

The male and female students live in a stable family context, most of them with one or more siblings, and belong to a low-middle socioeconomic context. It is confirmed that the fathers have a higher level of Education than the mothers (and a better work situation), and the level of studies of parents is higher for students of Baccalaureate than Vocational Modules.

The employment situation in families of Baccalaureate students is also more stable: of the four unemployed parents, three are of VM students. In both cases, half of the mothers work outside the home, which means that the other half are housewives.

These are students who have a long history of schooling, which began in Infant School. But this trajectory has had a different path for those who are in High School and those who are in Vocational Courses.

In our study, in short, we find two types of trajectories: those of high school students, who have had a stable trajectory, without repetitions and with a satisfactory experiential transit through the ESO; and those who study Vocational Courses, with more difficult trajectories, with repetitions and, above all, with frustrating life experiences in Secondary.

In this work, we are going to focus on those results that show differences in attitudes towards school culture, trying to investigate the factors that influence such differences between boys and girls, although there are also notable differences between students of Vocational Courses and High School.

\footnotetext{
${ }^{6}$ Interviews with Teaching staff were also conducted, which we do not include here.
} 


\section{Research results and discussion of the study}

\subsection{Resistance to school culture: discipline and low school performance}

The results of our research show that a positive attitude towards class rules and respect for discipline is closely linked to school success. The male and female students interviewed agree that attending class and respecting the established norms -something that both do- is key to success in school and there are differences between boys and girls, especially in the first years of Secondary Education (1316 years). All agree that, in their experience, girls are better students and have a positive attitude towards school.

As students express in the interviews, the girls, "are calmer, more attentive" (Araceli), "tend to be more predisposed to participate" (Gaby), perhaps -she adds- because they mature earlier and "do not feel the need to play the fool". Because "they attach more importance to studies, they are more orderly and they have another way of studying too [...], the boys have other interests" (Cristóbal). In fact, girls say they enjoy learning more than boys because they feel supported and welcomed in the school (GORARD; SEE, 2011).

In the opinion of some students (and in agreement with the Teaching staff), girls seem to be more interested than boys in study and school work, they mature earlier and do not feel the need to be funny in class unlike what usually happens to boys, coinciding with other research (FRANCIS; READ; SKELTON, 2009; WARRINGTON; YOUNGER; WILLIAMS, 2000).

In that sense, boys show a particular relationship between their construction of masculinity and their experience of school work (RODRÍGUEZ MARTÍNEZ; BLANCO GARCÍA, 2015; RODRÍGUEZ MENÉNDEZ, 2007; SUKHNANDAN; KELLEHER, 2000), seeking the acceptance of their classmates. To this end, they avoid appearing to be applied in the early courses of high school, frequently creating climates of confrontation to school rules and discipline to achieve a leadership that is contrary to good school performance. These match with some research (JACKSON, 1998) that reveals that some boys participate actively in their low performance as a sign of rejection of the school culture.

In our study, they use it as a resistance to the power relations imposed by the school and it translates into conflicts in the classroom that prevent the classroom from functioning normally, for which they often use humour as a form of confrontation. 
Data from inquiries (GARCÍA et al., 2013) and international reports also affirm that they show a lower school performance at the age of fifteen, where $60 \%$ of male students have a low performance (OECD, 2015a) and a higher number of course repetitions (OECD, 2015b; INEE, 2017), which are the cause of greater school dropout (EC, 2017).

\subsection{Involvement and commitment to studies}

On the other hand, we also found that the involvement and the commitment to studies happens because it makes them feel integrated and accepted in class, as emphasized by both male and female students that have participated in our investigation. Having friendships is very important because they are worried about the image they give to their classmates and here the demand will be different for boys and girls.

Several male and female authors agree on the importance of feeling part of a group in which they are accepted, above all, in adolescence (AKEY, 2006; FRANCIS; READ; SKELTON, 2009). Social relations in the classroom and in the centre create a sense of belonging and personal legitimacy of the students, due to the importance of being accepted and valued by their peers, as well as having the reference of other successful students (ABAJO; CARRASCO, 2004; CREA, 2010).

In our study, the image they have for their "colleagues" is vital, although some girls and boys do not relate in the same way at these ages. The girls create, to a greater extent, supportive relationships to studies and esteem of school life, while some boys seek to exercise resistance to school culture through disruptive behaviour in the classroom, even rejecting some boys who show an interest in studies. This happens, above all, in the first years of ESO (Compulsory Secondary Education, 14-16 years).

The commitment and involvement in studies depends on the life project itself, but that does not mean that they do not experience their schooling process with a sense in the present, as one female student expresses: "It works for me, day by day, and to get a job in the future" (Isabel).

The fact of knowing transcends the projection to work and in the future to do better in the world. Studying makes sense to get an Education, to obtain a job you like, to have culture and be independent, as expressed by the majority: "Not only learning new things, but rather you are maturing [...]. They are doors that open up to you" (Lola). Having a vital project defined in relation to studies, it generates commitment to the school, which results in good academic results 
(AKEY, 2006) and in a positive relationship with knowledge (CHARLOT, 2007), which allows them to feel satisfied with what they do (GORARD; SEE, 2011), as the students themselves indicate to us.

Francis, Read and Skelton (2009) also point out, as the first conclusion of their research on high-achieving students, that they actively participate in school activities, do their homework and that they are proud of their academic success. This intrinsic interest that supposes perseverance in class and in the daily work is something common in boys and girls. "Classwork I do every day" (Jaime); "I take notes in all classes and then organise them" (Raquel).

\subsection{Influence of the family and the Teaching staff}

The weight of the family environment is reduced as the school journey progresses (HERNÁNDEZ; TORT, 2009), but the influence of having people who trust or have trusted in both male and female students represents a "push" towards school success (MARTÍNEZ GARCÍA, 2011). This is a fundamental condition to be able to have early experiences of success, which have been particularly significant in developing trajectories of school continuity (ABAJO; CARRASCO, 2004; GARCÍA et al., 2013.

Our students, boys and girls, acknowledge the fundamental importance of the family. They feel supported and value the possibilities offered to them to continue studying, the trust and the expectations that they place in both boys and girls.

Girls, quite commonly, refer to the importance of their mothers, the support they provide and the value they give to what they think and expect of them. Many believe that their mothers value them very positively in relation to school (something that is related to their desire to reach educational levels that their mothers could not have), which already emerged in a study focused on 4th year students of Compulsory Secondary Education (GARCÍA GÓMEZ; PADILLA; SUÁREZ, 2009).

This also tallies with other research that shows the high intergenerational mobility, especially in girls, in which the aspirations and high expectations of mothers influence, especially when they have little academic Education, which also occurs in our research. The girls seem to have the value of studies more ingrained in their life project and show a desire to expand their possibilities and have more life and work options than their parents, especially their mothers or other women in the family (MARCENARO, 2010). 
Raquel is an example of the influence of the family, in this case her mother, and the desire to have a better life by continuing Higher Education. She feels proud to be the first person to study in her family. Or Sonia, who recognises that she does not want to have the life of her mother: "I want to study because I don't want to have that life (that of the mother), I don't want to be a housewife".

Despite the positive influence of families and in particular of mothers to achieve continuity and success in studies, the gender gap remains in the choice of career. Four times as many boys than girls plan to pursue a career in computer science or engineering, which will be reinforced by the expectation of families, while the expectations for the girls are linked to health and care-related professions (OECD, 2015b).

Although having a positive relationship with the teacher, or not having it, can significantly mark the concept of Education (AKEY, 2006; FRANCIS; READ; SKELTON, 2009; GORARD; SEE, 2011; OECD, 2009), in our research this aspect has not been highlighted by the students in general and even less for the Secondary teachers.

\section{Conclusions}

As we have analysed at the beginning of this paper, the Reports of the Programme for International Student Assessment, PISA (OECD, 2015a; 2015b; 2015c), of the European Commission (EC, 2017) and the Spanish State System of Indicators (INEE, 2017) have highlighted the existing gender gap in performance and attitudes towards school culture in favour of girls, which is also corroborated in our research.

However, we believe that it is not only gender that determines these differences, but also the social class and the level of Education of the family, as our research shows. And, coinciding with other studies, it is personal, relational and educational factors that attract young people towards the construction of a clearer commitment to school work and the continuity of their studies, as highlighted by Jackson et al. (2007), Martínez García (2011) and Mediavilla and Gallego (2016).

In addition, we found that girls show an intrinsic motivation towards studies, which is favoured by the influence of peers (AKEY, 2006; FRANCIS; READ; SKELTON, 2009) and of mothers towards them (MARCERANO, 2010), impacting on their positive attitudes towards schoolwork and educational success. This is also influenced by having good relationships with faculty and experiencing 
attractive pedagogies, as Gorard and See (2011) also show. This has meant a rise in the social level of girls in recent years, overcoming the effects of the social context of origin (ABAJO; CARRASCO, 2004; CREA, 2010).

In our study, mothers are a reference for the life project that school represents for female students, while their female friends represent support that favours a climate of greater integration in the school. The evidence shows that intergenerational mobility is higher in girls than in their mothers, who have high expectations of school continuity (MARCENARO; 2010; PADILLA, SUÁREZ; GARCÍA, 2007). The family environment in general is an incentive for the school trajectories of students (MARTÍNEZ GARCÍA, 2011), when it is an environment of trust for boys and girls, which has a very favourable effect on school continuity trajectories.

On the other hand, we find that the social construction of masculinity and femininity also exerts a notable influence on the attitudes shown by boys and girls towards school, as corroborated by our research. In this regard, authors such as Skelton, Francis and Read (2009), also find that the bad behaviour shown by some boys and the better adaptation of girls to school culture is not so much explained by a stereotyped model of social reproduction of students, which will make their actions more complacent and submissive to order and discipline (FERNÁNDEZ ENGUITA, 2009; KEDDIE, 2005; MARTÍNEZ GARCÍA, 2011), but by positive attitudes towards school and school work where they find opportunities for a different life project.

For a greater number of students, the school represents the opportunity to build a vital project. For them, however, in a greater proportion, school is a waste of time (OECD, 2015a). This attitude towards school on the part of boys is particularly worrying in the case of Spain, where, as we have seen, early school leaving rates are particularly high $(\mathrm{EC}, 2017)$ and where there are more repeaters per year according to the European average (OECD, 2009; 2015a). Differences in attitude and behaviour in secondary school children are a source of dissatisfaction leading to decoupling from school and school dropout.

In sum, we find that the social archetypes around the traditional sexual division of labour according to established gender roles (OECD, 2015b) seem to reinforce the disaffection of a greater number of boys towards school. For their part, girls' more positive attitudes towards studies and their involvement in school serve, as shown by international reports (OECD, 2015a; 2015b; 2015c) and our own research, to promote their success in educational institutions. 
In order to encourage positive attitudes towards school culture, we find that a good classroom climate is essential, as it allows students to increase their commitment, motivation, positive assessment of learning, enthusiasm, interest and pride in success on the part of students. Akey $(2006$, p. 3) indicates that "the level of participation and the intrinsic interest that a student shows towards school" is essential in developing a successful experience, and includes both behaviour (persistence, effort, attention) as well as attitudes (motivation, positive appraisal of learning, enthusiasm, interest and pride in success).

The topic of the more positive attitudes of girls is reflected in the international reports on the greater dedication to school tasks, seven hours a week compared to four hours of the boys, and in their better educational performance (OECD, 2015a; 2015b). This ties in with the assertion that disruptive environments cause disaffection in studies and that the majority of school dropouts occur at age 16.

Finally, it is worth mentioning that to the gender gap in school performance and attitudes, we must also add the gender gap that exists in the access that girls have to the fields of study, being still very underrepresented in STEM (OECD, 2015b), as we have analysed at the beginning of this work, of which we have some evidence despite being high school and vocational training students and being a theoretical sample.

Schools and families seem to foster different attitudes and levels of confidence in subjects according to gender, while reinforcing gender stereotypes in their professional expectations. In addition, the structure of the jobs leads to more difficult jobs in professions considered masculine as the reports show.

In any case, the differences observed in the performance of boys and girls towards subjects such as reading, mathematics and science are not due to inherent issues between boys and girls, rather because society and the school foster different attitudes, confidence and expectations towards one or another subject according to the stereotypes projected for each sex (OECD, 2015b; 2015c).

We found that there are social, structural and behavioural factors that explain these differences, as well as the OECD's international reports (2015a; 2015b; 2015c), regardless of the socio-cultural differences of origin that may exist. We understand that the challenge is not only to retain the boys within the educational institutions from the age of 16 , but to achieve the motivation of our young people towards their studies and the educational success without being limited by gender differences. 


\section{Diferenças de gênero no desempenho escolar e atitudes em relação à escola}

\section{Resumo}

Este artigo trata de diferenças de gênero no desempenho escolar e atitudes em relação à escola usando relatórios de dados de avaliações nacionais e internacionais e pesquisa qualitativa para compreender as percepções dos estudantes do Ensino Médio que continuaram seus estudos e o fizeram com sucesso. Com uma amostra de 20 alunos (12 meninas e 14 meninos) que estudam Bacharelado e Formação Profissional, investigamos, através de entrevistas em profundidade, a conformação de identidades femininas $e$ masculinas definidas tanto na reprodução de padrões culturais estereotipados, bem como na resistência e na ruptura. Os resultados mostram que as meninas têm um compromisso mais claro com o trabalho escolar, sendo ainda subrepresentadas em estudos técnicos, cuja importância no mercado de trabalho é superior.

Palavras-chave: Gênero. Realizações escolares. Atitudes em relação à escola. Avaliações internacionais.

\section{Diferencias de género en rendimiento escolar y actitudes hacia la escuela}

\section{Resumen}

En este articulo abordamos las diferencias de género en rendimiento escolar y actitudes hacia la escuela utilizando datos de informes de evaluaciones nacionales e internacionales y una investigación de indole cualitativo para comprender las percepciones de alumnas $y$ alumnos de secundaria postobligatoria que continúan los estudios y lo hacen con éxito. Con una muestra de veintiséis estudiantes (12 chicas y 14 chicos) que cursan Bachillerato y Formación Profesional, indagamos a través de entrevistas en profundidad la conformación de identidades femeninas y masculinas definidas tanto en la reproducción de patrones culturales estereotipados como en la resistencia y la ruptura. Los resultados muestran que las chicas tienen un compromiso más claro hacia el trabajo escolar, estando aún subrepresentadas en estudios técnicos cuya importancia en el mercado de trabajo es superior.

Palabras clave: Género. Rendimiento escolar. Actitudes hacia la escuela. Evaluaciones internacionales. 


\section{References}

ABAJO, J. E.; CARRASCO, S. (eds.). Experiencias y trayectorias de éxito escolar de gitanas y gitanos en España. Madrid: Cide, 2004.

AKEY, T. School context, student attitudes and behavior, and academic achievement: an exploratory analysis. New York: MDRC, 2006. Available in: https://files.eric.ed.gov/fulltext/ED489760.pdf. Access in: 11 nov. 2018.

AMOROS, C.; DE MIGUEL, A. Teoría feminista: de la ilustración a la globalización. Madrid: Minerva, 2005.

ANGROSINO, M. Etnografía y observación participante. Madrid: Morata, 2012.

BAPTISTE, A.; BELISLE, C. Photolangage: une methode pour communiquer en groupe par la photo. Paris: Editions d'Organisation, 1991.

BLANCO, N.; RODRÍGUEZ, C. La actitud y el compromiso hacia la escuela en estudiantes de secundaria considerados de éxito escolar. Infancia y Aprendizaje, [s. 1.], v. 38, n. 3, p. 542-568, jun. 2015.

BLICKENSTAFF, J.C. Women and science careers: leaky pipeline or gender filter? Gender and Education, Abingdon, v. 17, n. 4, p. 369-386, Aug. 2006. https://doi.org/10.1080/09540250500145072

CHARLOT, B. La relación con el saber. elementos para una teoría. Argentina: Libros del Zorzal, 2007.

CONNELL, R. Masculinidades. México: UNMA, 2003.

CREACIÓN DE RECURSOS EDUCATIVOS ABIERTOS - Crea. Gitanos: de los mercadillos a la escuela y del instituto al futuro. Madrid: MEC, 2010.

EURYDICE. La repetición de curso en la educación obligatoria en Europa: normativa y estadísticas. Madrid: Ministerio de Educación, 2011. Available in: $<$ http://eacea.ec.europa.eu/education/eurydice/documents/thematic_ reports/126ES.pdf $>$. Access in: 4 Aug. 2018.

EUROPEAN COMMISSION - EC. Education and training monitor. Luxenbourg: European Union, 2017. Available on: http:// ec.europa.eu/education/sites/education/files/monitor2017_en.pdf. Access in: 15 Feb. 2018. 
FERNÁNDEZ ENGUITA, M. La profesión docente en España: reflexiones y sugerencias. In: Puelles Benítez, M. (coord.). Profesión y vocación docente: presente y futuro. Madrid: Biblioteca Nueva-Escuela Julián Besteiro, 2009. p. 119-38.

FRANCIS, B.; SKELTON, C. Reassesing gender and achievement. London: Routledge, 2005.

FRANCIS, B.; READ, B.; SKELTON, C. The simultaneous production of educational achievement and popularity: How do some pupils accomplish it? British Educational Research Journal, Oxford, v. 36, n. 2, p. 317-340, Apr. 2010. https://doi.org/10.1080/01411920902919265

Fundación Secretariado Gitano - FSG. Incorporación y trayectorias de niñas gitanas en la ESO. Madrid: Cide, 2006.

GARCÍA, M. et al. Itinerarios de abandono escolar y transiciones tras la enseñanza secundaria obligatoria. Revista de Educación, Madrid, n. 361, p. 65-94, may-aug. 2013.

GARCÍA GÓMEZ, S.; PADILLA, M.T.; SUÁREZ, M. Los intereses académicos y profesionales de chicas que finalizan la escolaridad obligatoria. Revista de Educación, Madrid, n. 349, p. 311-4, may-aug. 2009.

GORARD, S.; SEE, B. How can we enhace enjoyment of secondary school? The student view. British Educational Research Journal, Oxford, v. 37, n. 4, p. 671-690, aug. 2011. https://doi.org/10.1080/01411926.2010.488718

HERNÁNDEZ, F.; TORT, A. Cambiar la mirada sobre el fracaso escolar desde la relación de los jóvenes con el saber. Revista Iberoamericana de Educación, Madrid, v. 49, n. 8, 1-11, 2009.

HOLDEN, C. Contributing to the debate: the perspective of children on gender, achievement and literacy. Journal of Education Enquiry, [s. 1.], v. 3, n. 1, p. 97-110, 2002.

INSTITUTO NACIONAL DE EVALUACIÓN EDUCATIVA - INEE. Sistema estatal de indicadores de la educación. Madrid: Secretaría General Técnica, Ministerio de Educación Cultura y Deporte, 2017.

JACKSON, M. et al. Primary and secondary effects in class differentials in educational attainment: the transition to a-level courses in England and Wales. Acta Sociológica, Thousand Oaks, v. 50, n. 3, p. 211-229, Sep. 2007. https://doi.org/10.1177/0001699307080926 
JACKSON, D. Breaking out of the binary trap: Boys' underachievement, schooling and gender relations. In: Epstein, D. et al. (eds.). Failing boys? Issues in gender and achievement. Buckingham: Open University Press, 1998. p. 310-333.

KEDDIE, A. On fighting and football: gender justice and theories of identity construction. International Journal of Qualitative Studies in Education, London, v. 18, n. 4, p. 425-444, July 2005. https://doi.org/10.1080/09518390500137600

KVALE, S. Las entrevistas en investigación cualitativa. Madrid: Morata, 2011.

MARCENARO, O. La educación como factor determinante de la movilidad intergeneracional en Andalucía. Sevilla: Centro de Estudios Andaluces, 2010.

MARTÍNEZ GARCÍA, J. S. Género y origen social: diferencias grandes en fracaso escolar administrativo y bajas en rendimiento educativo. Revista de la Asociación de Sociología de la Educación, [s. 1.], v. 4, n. 3, p. 270-285, jan. 2011.

MEDIAVILLA, M.; GALLEGO, L. Condicionantes del rendimiento académico en la escolaridad primaria en Brasil. Un análisis multifactorial. Educaçao \& Sociedade, Campinas, v. 37, n. 3, p. 195-216, jan./mar. 2016. https://doi.org/10.1590/ES0101-7330201683265

\section{ORGANIZATION FOR ECONOMIC COOPERATION AND} DEVELOPMENT - OECD. Panorama de la Educación 2018: indicadores de la OECD: informe español. Madrid: Ministerio de Educación y Formación Profesional, 2018.

\section{ORGANIZATION FOR ECONOMIC COOPERATION AND}

DEVELOPMENT - OECD. Equally prepared for life? How 15-year-old boys and girls perform in school. Paris: PISA-OCDE, 2009.

ORGANIZATION FOR ECONOMIC COOPERATION AND DEVELOPMENT - OECD. The ABC of gender equality in education: aptitude, behavoir, confidence. Paris: PISA- OCDE, 2015a.

ORGANIZATION FOR ECONOMIC COOPERATION AND DEVELOPMENT - OECD. Trends shaping education spotlight 7: gender equality. Paris, 2015b. Available on: http://www.oecd.org/education/ceri/ Spotlight7-GenderEquality.pdf, Access in: 20 Feb. 2017. 


\section{ORGANIZATION FOR ECONOMIC COOPERATION AND}

DEVELOPMENT - OECD. What lies behind gender inequality in education? Paris, 2015c. (PISA in Focus, vol. 49). Available on: http://dx.doi. org/10.1787/5js4xffhhc30-en. Access in: 10 jun. 2018.

ORGANIZATION FOR ECONOMIC COOPERATION AND DEVELOPMENT - OECD. PISA 2015: Programa para la evaluación internacional de los alumnos. Madrid: INEE, 2015. (Subdirección general de documentos y publicaciones, 2016). Available on: https://goo.g17tmAHP. Access in: 15 jun. 2018.

PADILLA, M. T.; SUÁREZ, M.; GARCÍA, S. Elecciones educativas y vocacionales de las chicas onubenses que finalizan la ESO: comparación de sus expectativas, con las de sus docentes y familias. XXI. Revista de Educación, Huelva, n. 9, p. 75-94, 2007.

PERRENOUD, P. H. La construcción del éxito y del fracaso escolar. Madrid: Morata, 1990.

POSADA, L. Filosofía y epistemología desde la impronta feminista. In: COBO, R. (ed.). La imaginación feminista: debates y transformaciones disciplinares. Madrid: Catarata, 2019. p. 255-82.

RENOLD, E.; ALLAN, A. Bright and beautiful: high achieving girls, ambivalent femmininities and the feminization of succes in the primary school. Studies in the Cultural Politics of Education, London, v. 27, n. 4, p. 457-73, 2006. https://doi.org/10.1080/01596300600988606

RODRÍGUEZ MARTÍNEZ, C.; BLANCO GARCÍA, N. Diferencias de género, abandono escolar y continuidad en los estudios. Revista Iberoamericana de Educación, Madrid, n. 68, p. 59-78, mayo 2015. https://doi.org/10.35362/rie680200

RODRÍGUEZ MENÉNDEZ, C. Identidad masculina y contexto escolar: notas para un debate. Revista de Educación, Madrid, n. 342, p. 397-418, ene. 2007.

SKELTON, C, FRANCIS, B.; READ, B. Brains before 'beauty'? High achieving girls, school and gender identities. Educational Studies, London, v. 36, n. 2, p. 185-194, 2010. https://doi.org/10.1080/03055690903162366

SIERRA, J. E. La secundaria vivida: estudio narrativo sobre experiencias masculinas de fracaso escolar. (Tesis doctoral - Didáctica y Organización Escolar) - Facultad de Ciencias de la Educacióon, Universidad de Málaga, Málaga, 2013. 
SUKHNANDAN, L.; KELLEHER, S. An investigation into gender differences in achievement. Phase 2: School an classroom strategies. Slough: NFER, 2000.

WARRINGTON, M.; YOUNGER, M.; WILLIAMS, J. Students attitudes, image and the gender gap. British Educational Research Journal, London, v. 26, n. 3, p. 393-407, June 2000. https://doi.org/10.1080/01411920050030914

\section{Informations about authors}

Carmen Rodríguez Martínez: PhD in Pedagogy from the University of Malaga. Full Professor in the Department of Didactics and School Organization at the University of Malaga (Spain). Coordinator of the Master "Educational Innovation Policies and Practices". Principal Investigator of the National R\&D Plan project: "New educational policies and their impact on equity: school management and teacher professional development". Contact: carmenrodri@uma.es

iD https://orcid.org/0000-0002-0423-458X

Monsalud Gallardo Gil: PhD in Education Sciences from the University of Malaga (Spain). Assistant Professor in the Department of Didactics and School Organization of the Faculty of Education Sciences of the University of Malaga. Researcher of the Research Group: "Innovation and Educational Evaluation in Andalusia" (HUM-311), directed by Mr. Ángel I. Pérez Gómez. Contact: monsalud@uma.es.

iD https://orcid.org/0000-0003-4068-2133 